\title{
DEVELOPMENTAL CHANGES IN LACTATE DEHYDROGENASE ISOENZYMES IN THE TESTIS OF THE IMMATURE RAT
}

\author{
A. W. BLAGKSHAW AND J. S. H. ELKINGTON \\ Department of Physiology, University of Queensland, \\ Brisbane, Queensland 4067, Australia
}

(Received 8th April 1969)

\begin{abstract}
Summary. The body and testis weights increase linearly with time during growth of the immature rat. Between 20 and 30 days of age, there is an increase in lactate dehydrogenase ( $\mathbf{L D H})$ activity in the interstitial and tubular tissue of the testis and glucose-6-phosphate dehydrogenase (G-6-PDH) in the interstitial cells. LDH-X isoenzymes appear between 20 and 30 days of age and are associated with the seminiferous tubular epithelium. There is a linear increase in seminiferous tubule diameter with age until 60 days, after which time there is no further tubular growth.
\end{abstract}

\section{INTRODUCTION}

Lactate dehydrogenase was shown by Niemi \& Ikonen (1962) and Ito (1966) to be located mainly in the interstitial tissue of both the foetal and adult rat testis. In the bull testis, this enzyme has been found mainly in the spermatogonia and spermatocytes, with less activity in the interstitial tissue (Blackshaw \& Samisoni, 1967a).

The molecular heterogeneity of lactate dehydrogenase (LDH) was recognized as early as 1950 but it was not until 1959 that Markert \& Møller demonstrated the existence of five multimolecular forms or isoenzymes in mammalian tissue. In structure, these isoenzymes are tetramers of two parental subunits, A (muscle) and B (heart) (Appella \& Markert, 1961).

It has since been shown that the normal adult testis of some species; man (Blanco \& Zinkham, 1963; Goldberg, 1964), rabbit, mouse, dog, guinea-pig, bull and pigeon (Zinkham, Blanco \& Clowry, 1964); contain unusual isoenzymes of lactate dehydrogenase designated LDH-X, and composed of $\mathrm{C}$ subunits (Zinkham et al., 1964) distinct from the A and B subunits of other LDH isoenzymes (Appella \& Markert, 1961). The developmental changes in LDH isoenzymes of the testis have been little studied (Zinkham $e t$ al., 1964) but Goldberg \& Hawtrey (1967) showed in the mouse testis that LDH-X appears between 15 and 17 days post partum, which corresponds to the first appearance of 
pachytene primary spermatocytes in the testis (Nebel, Amorose \& Hackett, 1961).

Glucose-6-phosphate dehydrogenase (G-6-PDH) has been shown also to be located mainly in the Leydig cells of the human adult and foetal testis (Wolfe \& Cohen, 1964; Niemi, Ikonen \& Harkonen, 1967) and bull testis (Blackshaw \& Samisoni, 1967a), with some activity in bull spermatozoa.

This paper describes experiments with the rat testis showing developmental changes from 20 to 70 days of age in histology, $\mathrm{LDH}$ histochemistry and isoenzymes, and G-6-PDH histochemistry.

\section{MATERIALS AND METHODS}

Male Wistar rats (maintained on commercial pellets and water), were randomly divided at 20,30,40,50,60 and 70 days post partum into six groups of eight animals each. The animals were killed by cervical dislocation and weighed. The seminal vesicles (empty of secretion) and the testes were weighed. One testis was rapidly frozen to a stainless steel microtome chuck, in a dry iceacetone mixture, for histological and histochemical studies.

A $10 \%$ homogenate was made of the second testis in $0.9 \%$ saline using a motor-driven glass homogenizer fitted with a Teflon pestle. The homogenate was immediately centrifuged at $6000 \mathrm{~g}$ for $30 \mathrm{~min}$ at $5^{\circ} \mathrm{C}$ (International Portable Refrigerated Centrifuge Model PR-2). The supernatant was diluted ten times and used for total LDH assay (Wilkinson, 1962) with both sodium pyruvate and 2-oxobutyrate as substrates. Total protein estimates were made by the ultraviolet method described by Layne (1957).

The isoenzymes of lactate dehydrogenase were separated by polyacrylamide gel disc electrophoresis (Blackshaw \& Samisoni, 1966). Tetrazolium reductase activity was demonstrated, using nitro blue tetrazolium (NBT), as purple bands of formazan in the gel (Helm, Zondag, Hartog \& Kooi, 1962) with the substrates, sodium lactate to demonstrate LDH and sodium DL- $\alpha$-hydroxyvalerate for the LDH-X isoenzymes (Allen, 1961). The amount of formazan deposited in each isoenzyme band was estimated using an integrating densitometer (Photovolt Densicord 542) and the relative contributions of the stained areas calculated.

Thin sections $(10 \mu)$ of the testis were made with a Lipshaw cryotome at $-25^{\circ} \mathrm{C}$. Sections for dehydrogenase staining were placed on coverslips and sections for haematoxylin and eosin staining on slides. The enzymes studied were LDH and G-6-PDH (Hess, Scarpelli \& Pearse, 1958) using NBT; incubation times being $15 \mathrm{~min}$ for $\mathrm{LDH}$ and $30 \mathrm{~min}$ for G-6-PDH. The sections showing LDH and G-6-PDH activity were mounted directly in hydramount (Gurr) while haematoxylin and eosin stained sections were mounted in Dep-X (Gurr) after dehydration.

\section{RESULTS}

The isoenzymes of testicular LDH separated by polyacrylamide gel disc electrophoresis and stained by NBT reduction were identified by comparison 
of their mobilities with those of heart and liver extracts, and also by their specific reactions with sodium DL- $\alpha$-hydroxyvalerate. The stained isoenzymes were evaluated by the integrating densitometer and the relative proportions of

TABLE 1

THE EFFECT OF AGE ON THE RELATIVE AGTIVITY (\%) OF THE LDH ISOENZYMES OF RAT TESTIS (MEANS OF EIGHT READINGS)

\begin{tabular}{l|r|r|r|r|r|r}
\hline \multirow{2}{*}{ Isoenzyme } & \multicolumn{7}{|c}{$\begin{array}{c}\text { Age (days) } \\
(\% \text { contribution to total activity) }\end{array}$} \\
\cline { 2 - 7 } & 20 & 30 & 40 & 50 & 60 & 70 \\
\hline 1 & 44 & 40 & 39 & 43 & 46 & 46 \\
2 & 7 & 17 & 15 & 12 & 13 & 13 \\
3 & 9 & 7 & 10 & 5 & 6 & 3 \\
$4 \mathrm{a}$ & 27 & - & - & - & - & - \\
$4 \mathrm{~b}$ & 13 & - & - & - & - & - \\
$\mathrm{X}_{1}$ & - & 4 & 14 & 9 & 14 & -37 \\
$\mathrm{X}_{2}$ & - & 23 & 20 & 27 & 16 & 37 \\
5 & - & 9 & 3 & 6 & 6 & 2 \\
\hline
\end{tabular}
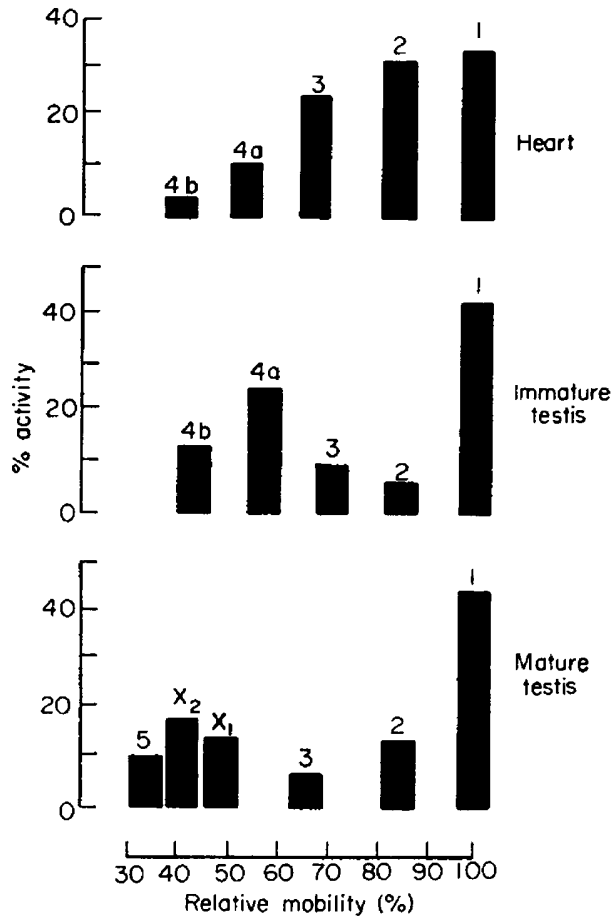

Text-pig. 1. The relative mobilities and activity of the isoenzymes of lactate dehydrogenase of rat heart, immature testis (20 days) and mature testis ( 70 days).

each isoenzyme calculated for the different age groups (Table 1). At 20 days of age, the LDH isoenzyme pattern of the testis was similar to that of adult rat heart; LDH-X appeared between 20 and 30 days of age as two isoenzymes $-\mathrm{X}_{1},-\mathrm{X}_{2}$ reacting with valerate (Text-fig. 1 ). 
To assess quantitatively the enzyme activity of the testis at different ages, only the specific isoenzymes $\mathrm{LDH}-\mathrm{X}_{1},-\mathrm{X}_{2}$ were used and the total contribution of LDH-X was expressed as $\mathbf{C}$ subunit activity (Table 2). There was no significant change in the specific activity of LDH-X after its appearance in the testis, but activity per gram of testis did show a significant increase coinciding with proliferation of the tubular epithelium and change of primary spermatocytes from the resting to the pachytene stage of meiosis.

TABLE 2

THE EFFECT OF AGE ON AGTIVITY OF C SUBUNITS OF RAT TESTIGULAR LDH (MEANS OF EIGHT READINGS)

\begin{tabular}{|c|c|c|c|}
\hline \multirow[b]{2}{*}{ Age (days) } & \multicolumn{3}{|c|}{$C$ subunit activity } \\
\hline & per 1 mg protein & $\begin{array}{c}\text { per } 1 g \text { testis } \\
\left(\times 10^{-3}\right)\end{array}$ & $\begin{array}{c}\text { per testes } \\
\left(\times 10^{-3}\right)\end{array}$ \\
\hline $\begin{array}{l}20 \\
30 \\
40 \\
50 \\
60 \\
70\end{array}$ & $\begin{array}{r}0.0 \\
33 \cdot 9 \\
47 \cdot 4 \\
42 \cdot 0 \\
55 \cdot 7 \\
53.4\end{array}$ & $\begin{array}{r}0.0 \\
43 \cdot 1 \\
60 \cdot 1 \\
55 \cdot 8 \\
42 \cdot 4 \\
46 \cdot 4\end{array}$ & $\begin{array}{r}0.0 \\
23.2 \\
58.9 \\
69 \cdot 6 \\
75 \cdot 7 \\
102.0\end{array}$ \\
\hline
\end{tabular}

Summary analyses of variance (excluding data for Day 20)

\begin{tabular}{l|c|ccc}
\hline & & \multicolumn{3}{|c}{ Variance ratios } \\
$\begin{array}{c}\text { Source } \\
\text { of } \\
\text { variation }\end{array}$ & $\begin{array}{c}\text { Degrees } \\
\text { of } \\
\text { freedom }\end{array}$ & per $1 \mathrm{mg}$ protein & $\begin{array}{c}\text { C subunit activity } \\
\text { per } 1 \mathrm{~g} \text { testis }\end{array}$ & per testes \\
\hline Time & 4 & $1 \cdot 3$ & $3 \cdot 2^{*}$ & $10 \cdot 4^{* *}$ \\
Readings & 7 & $1 \cdot 0$ & $1 \cdot 2$ & $0 \cdot 6$ \\
Error variance & 28 & $47319 \cdot 0$ & $15661 \cdot 0$ & $63307 \cdot 0$ \\
\hline
\end{tabular}

The appropriate error variance is given at the foot of each variance ratio column. $* P<0 \cdot 05 ; * * P<0 \cdot 01$.

Similarly, total LDH-X activity in each testis showed significant increases.

As a further assessment of the metabolic state of the maturing rat testis, measurements of the histochemical activity of lactate-reactive LDH (Table 3) and G-6-PDH (Table 4) in various regions of the testis were made by scoring staining intensity on a scale of 0 to 5 . In the interstitial cells, both LDH (Pl. 1, Fig. 1) and G-6-PDH (Pl. 1, Fig. 2) were extremely active, but LDH was present at least 10 days before G-6-PDH. Activity of LDH in the spermatogenic cells was most marked in the early stages of testicular development, and was seen in the first spermatozoa at 50 days.

\section{EXPLANATION OF PLATE 1}

FIG. 1. Lactate dehydrogenase (LDH) activity, with lactate as substrate, in the testis of the 60 -day rat. $\times 150$.

FIG. 2. Glucose-6-phosphate dehydrogenase activity in the testis of the 60 -day rat. $\times 320$. FIG. 3. Lactate dehydrogenase (LDH-X) activity with $\alpha$-hydroxyvalerate as substrate in the testis of the 60 -day rat. $\times 150$. 
PLATE 1

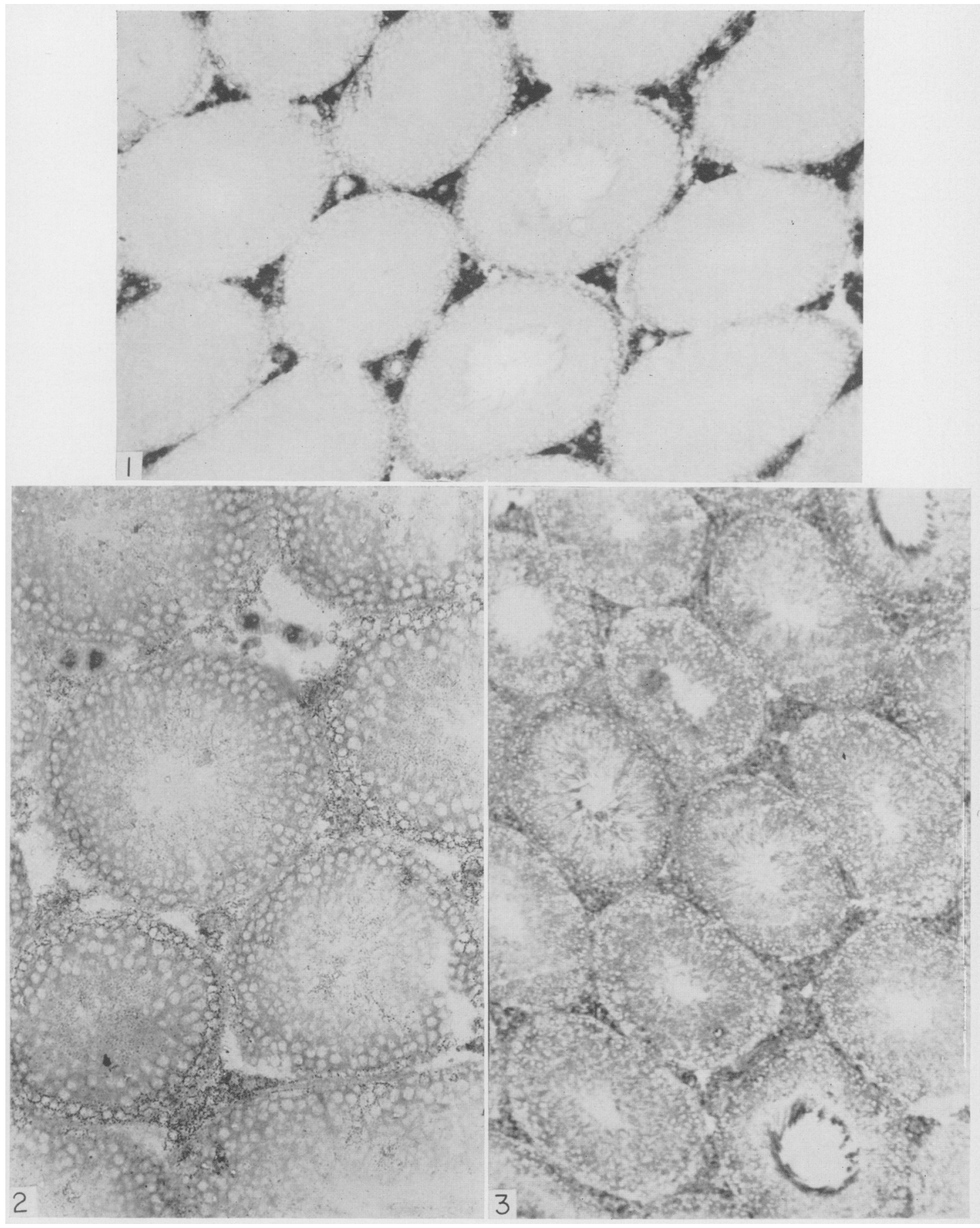


In sections of adult rat testis stained with NBT, and using valerate as substrate, there was strong LDH-X activity in the cells of the seminiferous epithelium, but not in the interstitial tissue (Pl. 1, Fig. 3). Glucose-6-phosphate dehydrogenase activity was most marked in the seminiferous tubule epithelium in the early stages of testicular development, but lagged 10 days behind LDH (Table 4).

TABLE 3

EFFECT OF AGE ON THE RELATIVE AGTIVITY OF LDH IN VARIOUS REGIONS OF THE TESTIS (MEANS OF FIVE READINGS)

\begin{tabular}{c|c|c|c}
\hline Age (days) & Interstitial cells & Tubule cells & Spermatozoa \\
\cline { 2 - 4 } 20 & 1.8 & 0.4 & 0.0 \\
30 & 3.6 & $2 \cdot 4$ & 0.0 \\
40 & 3.6 & 2.8 & 0.0 \\
50 & 3.2 & 1.2 & 0.4 \\
60 & 4.8 & 0.6 & 0.6 \\
70 & 4.4 & 1.8 & 0.6 \\
\hline
\end{tabular}

Visual estimates of formazan (NBT) intensity were made using a scale of 0 to 5 .

TABLE 4

EFFEGT OF AGE ON THE RELATIVE AGTIVITY OF G-6-PDH IN VARIOUS REGIONS OF THE RAT TESTIS (MEANS OF FIVE READINGS)

\begin{tabular}{c|c|c|c}
\hline Age (days) & Interstitial cells & Tubule cells & Spermatozoa \\
\hline 20 & $0 \cdot 0$ & $0 \cdot 0$ & $0 \cdot 0$ \\
30 & $0 \cdot 2$ & $0 \cdot 2$ & $0 \cdot 0$ \\
40 & $3 \cdot 0$ & $1 \cdot 6$ & $0 \cdot 0$ \\
50 & $1 \cdot 8$ & $1 \cdot 4$ & $0 \cdot 0$ \\
60 & $3 \cdot 0$ & $1 \cdot 8$ & $0 \cdot 0$ \\
70 & $2 \cdot 0$ & $0 \cdot 6$ & $0 \cdot 8$ \\
\hline
\end{tabular}

Visual estimates of formazan (NBT) intensity were made using a scale of 0 to 5 .

A calibrated eyepiece micrometer was used to estimate the seminiferous tubule diameter in sections of the rat testis, stained with haematoxylin and eosin. These increased linearly in diameter from $138 \pm 5 \mu$ at 20 days to $346 \pm$ $13 \mu$ at 60 days and then showed no further significant change in size.

\section{DISCUSSION}

During maturation in the rat, body and testis weights increase linearly with time, while the seminal vesicles show a rapid increase in size after 50 days (Inano, Hori \& Tamaoki, 1967).

Associated with growth of the seminiferous tubules, the first appearance of pachytene primary spermatocytes occurs between 20 and 30 days of age, and 
spermatozoa appear between 30 and 40 days (Clermont \& Perey, 1957; Niemi \& Kormano, 1965).

Histochemically, LDH-X is associated with the seminiferous tubule epithelium in the rat, as in the mouse (Allen, 1961; Goldberg \& Hawtrey, 1967; Blackshaw \& Elkington, 1967). There is a marked increase in tubular LDH activity between 20 and 30 days of age and the appearance of LDH-X at this time suggests that it is linked also to the first wave of pachytene primary spermatocytes, as in the mouse (Nebel et al., 1961). Further evidence for the tubular location of LDH-X is provided from the LDH pattern of ram spermatozoa (Blackshaw \& Samisoni, 1967b) and bull spermatozoa (Goldberg, 1964; Blackshaw \& Samisoni, 1967a; Blackshaw, Miller \& Graves, 1968) which have been shown to contain LDH-X only.

The importance of the LDH-X isoenzymes in the testis is still uncertain, but their appearance in the seminiferous epithelium at the same time as the pachytene primary spermatocytes may point to an important metabolic rôle in sperm production. As LDH-X is the only isoenzyme found in ram and bull spermatozoa, it may be necessary for maintaining the spermatozoa during their maturation in the epididymis and during their time in the female reproductive tract by the utilization of lactate in these areas (Clausen, 1969).

Beyond 20 days of age, the interstitial tissue of the rat testis changes from undifferentiated spindle cells to Leydig cells typical of the adult. After 50 days, testosterone effects a rapid growth of the seminal vesicles, its secretion being a result of the final enzymatic maturation of the Leydig cells (Inano et al., 1967). These authors have also shown that there are two phases of steroid production in the developing rat testis. Early in post-natal life, androstenedione reductase directs synthesis to androstenedione; as puberty approaches, the activity of $17 \beta$-hydroxysteroid dehydrogenase increases, while that of the reductase decreases and testosterone instead of androstenedione becomes the final product.

After 30 days, there was a considerable increase in the interstitial activity of glucose-6-phosphate dehydrogenase which provides NADPH for the cholesterol side-chain cleavage enzyme, this being essential in the synthesis of the hormonal steroids.

\section{REFERENGES}

Allen, J. M. (1961) Multiple forms of lactate dehydrogenase in tissues of the mouse: their specificity, cellular localization, and response to altered physiological conditions. Ann. N.Y. Acad. Sci. 94, 937.

APPELla, E. \& MARKERT, G. L. (1961) Dissociation of lactate dehydrogenase into subunits with guanidine hydrochloride. Biochem. biophys. Res. Commun. 6, 171.

Blackshaw, A. W. \& Elkington, J. S. H. (1967) Hormones and the isoenzymes of lactate dehydrogenase. Med. F. Aust. ii, 520.

Blackshaw, A. W., Miller, O. C. \& Graves, C. N. (1968) Lactate dehydrogenase isoenzymes of calf and adult bull testes. 7. Dairy Sci. 51, 950 .

Blackshaw, A. W. \& Samisoni, J. I. (1966) The effects of cryptorchism in the guinea pig on the isoenzymes of testicular lactate dehydrogenase. Aust. F. biol. Sci. 19, 841.

Blackshaw, A. W. \& Samisoni, J. I. (1967a) Histochemical localization of some dehydrogenase enzymes in the bull testis and epididymis. F. Dairy Sci. 50, 747.

Blackshaw, A. W. \& Samisoni, J. I. (1967b) The testes of the cryptorchid ram. Res. vet. Sci. 8, 187.

Blanco, A. \& Zinkham, W. H. (1963) Lactate dehydrogenase in human testis. Science, N.Y. 131, 601.

Cu.Ausen, J. (1969) Lactate dehydrogenase isoenzymes of sperm cells and testes. Biochem. F. 111, 207. 
Clermont, Y. \& Perey, B. (1957) Quantitative study of the cell population of the seminiferous tubules in immature rats. Am. F. Anat. 100, 241.

GoldeERG, E. (1964) Lactate dehydrogenase and malate dehydrogenase in sperm: studied by polyacrylamide gel electrophoresis. Ann. N.Y. Acad. Sci. 121, 560.

Goldberg, E. \& HaWTREY, C. (1967) The ontogeny of sperm specific lactate dehydrogenase in mice. 7. exp. Zool. 164, 309.

Helm, H. J. van der, Zondag, H. A., Hartog, H. A. \& Kooi, M. W. van der (1962) Lactate dehydrogenase isoenzymes in myocardial infarction. Clinica chim. Acta, 7, 540.

Hess, R., Scarpelli, D. G. \& Pearse, H. G. E. (1958) The cytochemical localization of oxidative enzymes. II. Pyridine nucleotide-linked dehydrogenases. F. biophys. biochem. Cytol. 4, 753.

Inano, H., Hori, Y. \& Tamaoki, B. (1967) Effects of age on testicular enzymes related to steroid bioconversion. Ciba Fdn Colloq. Endocr. 16, 105.

Iто, M. (1966) Histochemical observations of oxidative enzymes in irradiated testis and epididymis. Radiat. Res. 28, 266.

LAYNE, D. (1957) Spectrophotometric and turbidimetric methods for measuring proteins. In: Methods of Enzymology, Vol. III, p. 454. Eds. S. P. Colowick and N. O. Kaplan. Academic Press, New York.

Markert, C. L. \& Møller, F. (1959) Multiple forms of enzymes: Tissue, ontogenetic and species specific patterns. Proc. natn. Acad. Sci. U.S.A. 45, 753.

Nebel, B. R., Amorose, A. P. \& HAckett, E. M. (1961) Calendar of gametogenic development of the prepubertal male mouse. Science, $\mathcal{N}$. Y. 134, 832.

Niemi, M. \& Ikonen, M. (1962) Hypophysectomy and testis dehydrogenases. Endocrinology, 70, 167.

NiEmi, M., Ikonen, M. \& Harkonen, A. (1967) Histochemistry and fine structure of the interstitial tissue in the human foetal testis. Ciba Fdn Colloq. Endocr. 16, 31.

Nizmi, M. \& Kormano, M. (1965) Histochemical demonstration of a C-esterase activity in the seminiferous tubules of the rat testis. $\mathcal{F}$. Reprod. Fert. 10, 49.

Wilkinson, J. H. (1962) The dehydrogenases. In: An Introduction to Diagnostic Enzymology. Edward Arnold, London.

Wolfe, H. J. \& Cohen, R. B. (1964) Glucose-6-phosphate dehydrogenase activity in the human foetal and prepubertal testis: a histochemical study. F. clin. Endocr. Metab. 24, 616.

Zinkham, W. H., Blanco, A. \& Clowry, C. J. (1964) An unusual isoenzyme of lactate dehydrogenase in mature testes: Localization, ontogeny, and kinetic properties. Ann. N.Y. Acad. Sci. 121, 571. 